\title{
Construction of the Rehabilitation Model for Drug Abuse in Non-Penal Criminal Policy Perspective
}

\author{
Agah Sonjaya \\ Pasundan University, Bandung, INDONESIA
}

Received: 21 July 2020 - Accepted: 18 September 2020 - Published Online: 2 October 2020

\begin{abstract}
As mandated by the Law for drug addicts/abusers, rehabilitation is carried out. Meanwhile, the rules for drug addicts and psychotropic drugs or similar drugs that cause dependence and have a serious impact are not regulated normatively. So that in the law enforcement process, both Narcotics, Psychotropics and Drugs, Law No. 35 of 2009 concerning narcotics. In a practical level or reality in the field, the implementation of rehabilitation is very monotonous and the road is in place. Both the Narcotics Law, Seja, Sema and Perber all require that before waiting for the decision of the panel of judges concerned as a category of addicts must be placed in a rehabilitation institution. Of course, this is very worrying, how much will the rehabilitation process cost? Economically, this law enforcement model is ineffective, so the implementation of enforcement is in place.
\end{abstract}

Keywords: drug rehabilitation, rehabilitation model construction, non-penal policy.

\section{Introduction}

The era of globalization which is marked by the emergence of the Industrial Revolution 4.0, to be precise in $2020-2030,{ }^{1}$ is predicted to have the opportunity to receive a demographic bonus where the structure of Indonesia's population will be dominated by the productive age. It is hoped that this will have an impact on increasing community productivity and spurring economic growth and optimizing development significantly. However, these great opportunities can turn into disasters when we fail to manage these opportunities, for example, we fail to protect the "productive age" from the threat of drug abuse. It is worth watching out, data from the survey results of the National Narcotics Agency (BNN) in collaboration with the University of Indonesia (UI) Health Research Center in 2017 shows that the prevalence of drug abusers reaches $3,376,115$ people or $1.77 \%$ of the total population of productive age (10-59 years). ${ }^{2}$ The large number of abusers or prevalence figures will be a big threat to the demographic bonus, lest the demographic bonus that should be a bonus will turn into a disaster if we fail to suppress the rate of increasing the number of abusers.

As the leading sector for the implementation of the Prevention and Eradication of Narcotics Abuse and Illicit Narcotics (P4GN) program, the National Narcotics Agency (BNN) has

${ }^{1}$ Klaus Schwab, The Fourt Industrial Revolution, World Economic Forum, 2016.

${ }^{2}$ https://bnn.go.id/puncak-peringatan-hari-anti-narkotika-internasional-hani-2018/.

(C) Authors. Terms and conditions of Creative Commons Attribution 4.0 International (CC BY 4.0) apply. Correspondence: Agah Sonjaya, Doctorate Candidate of Law Science, Pasundan University, Bandung, INDONESIA. E-mail: agahsonjayash57@yahoo.com. 
prepared various policy instruments and carried out various activities to reduce the rate of increase in the number of abusers (prevalence) and together with POLRI (Republic Police of Indonesia) reveals the narcotics syndicate network to stop drug supplies from producing countries from entering Indonesia.

Based on quantitative data, estimates and projections of the number of drug users tend to be stable from 2017 to 2022. This happens because efforts to reduce the number of drug abuse have entered a stage that is increasingly difficult to reduce absolutely (hard rock), which is around 3.3 million people per year. Extra strategies for programs and activities that are more innovative and sustainable are needed so that they can significantly reduce both the prevention and law enforcement side, by setting targets for achievement that are much higher than today. 3

As an applicable effort in preventing and supplying narcotics for the sake of treatment and health services, one of the efforts of the government is to legally regulate the distribution, import, export, cultivation, use of narcotics in a controlled manner and strict supervision. ${ }^{4}$ So to prevent and eradicate abuse ${ }^{5}$ and the illicit trafficking of narcotics which has harmed and endangered the lives of the people, In this case the Indonesian government itself on September 14, 2009 has succeeded in compiling and ratifying the new Narcotics Law, namely Law Number 35 of 2009 concerning Narcotics. ${ }^{6}$

Efforts that can be realized are the enforcement of positive laws, namely Law No. 35 of 2009 concerning Narcotics, one of these efforts is to reform and strengthen the regulatory sector. Before Indonesia issued Law No. 35 of 2009, Indonesia has ratified the United Nations Convention Against Illicit Traffic in Narcotic Drugs and Psychotropic Substances through Law No. 7 of 1997 concerning the Ratification of the United Nations Convention on the Eradication of Illicit Narcotics and Psychotropics (1998).

Efforts to solve drug problems have been carried out in a cross-sectorial manner both from the "preventive" and "repressive" aspects through the existence of laws and regulations relating to narcotics. In particular, preventive efforts have been made, for example by officials with an interest, especially from the National Narcotics Agency (BNN), the Indonesian National Police and Civil Servant Officials (PPNS) as well as through active community participation, namely by the emergence of institutions established by the community including the campus

\footnotetext{
3 Badan Narkotika Nasional, Laporan Akhir Survei Nasional Perkembangan Penyalahguna Narkoba Tahun Anggaran 2017, 2017.

4 The circulation of narcotics must be closely monitored on the basis of the consideration that currently their use is mostly for negative things. In addition, through the development of information and communication technology, and the spread of narcotics which have also reached almost all regions of Indonesia. Areas that have never been touched by narcotics trafficking have gradually become the centers of narcotics trafficking. Likewise, children who are initially unfamiliar with this haram have turned into addicts who are difficult to let go of their dependence.

5 Mardani, Penyalahgunaan Narkoba (dalam Perspektif Hukum Islam dan Hukum Pidana Nasional), PT Raja Grafindo Persada: Jakarta, 2008, hlm: 1-2. In this book it is stated that: "Narcotics abuse is the use of drugs outside of medical indications without a doctor's instructions or prescription and its use is pathological (causes abnormalities) and causes obstacles in activities at home, school, campus, work place and social environment."

${ }^{6}$ Law No. 35/2009 is a refinement of Law No. 22/1997 which is deemed less likely to provide a deterrent effect and reduces the level of prevention both quantitatively and qualitatively on the distribution and use of narcotics. The existence of this new law also regulates the regulation of medical and social rehabilitation and the use of narcotics for medicinal and health purposes. Therefore, Law Number 35 of 2009 concerning Narcotics is the basis for law enforcement in order to ensure the availability of drugs for the benefit of science, technology, health and to prevent the abuse and illicit trafficking of narcotics. Siswanto S, Politik Hukum Dalam Undang - Undang Narkotik, Rineka Cipta: Jakarta, 2012, hlm: 83.
} 
community - campus that cares about the dangers of drugs. "Repressive" efforts have been carried out ranging from arrest to legal proceedings in court. However, until now the number of drug abusers has not decreased and it tends to increase. Drugs are also rife in prisons and even drug production has been found in prisons several times. ${ }^{7}$

Narcotics / drug addicts / the like are basically victims of the abuse of narcotics crimes that violate state laws, and they are all Indonesian citizens who are expected to be able to build this country from a downturn in almost all fields. In connection with the problem of narcotics abuse, a criminal law policy is needed that positions narcotics addicts as victims, not criminals.

Narcotics addicts are "self-victimizing victims", because narcotics addicts suffer from a "dependency syndrome" as a result of their own narcotics / drug abuse. ${ }^{8}$ It is interesting in law No. 35 of 2009 regarding narcotics, it is the judge's authority to issue a sentence for someone who is proven to be a narcotics addict for rehabilitation. Implicitly, this authority recognizes that narcotics addicts, apart from being the perpetrators of criminal acts, are also victims of the crime itself, which in terms of victimization is often referred to as self-victimization or victimless crime. The description in the article focuses on the judge's power in deciding narcotics cases. Unfortunately the formula is ineffective in reality. Trials of drug / drug addicts mostly end in imprisonment and not rehabilitation verdicts as stipulated in the law.

The approach used so far as a solution to reduce drug abuse rates can be seen from 2 (two) different points of view, the first is that prioritizes law enforcement efforts ("penal") by imposing criminal sanctions on drug abusers in order to get a deterrent effect, while on the side others use rehabilitation ("non-penal") measures to reduce the black market, which is assumed to have an effect on reducing the "demand" for drugs. Both "penal" and "non-penal" approaches, efforts to tackle the problem of narcotics addiction require appropriate policy steps and formulations so that the high rate of narcotics abuse in Indonesia can be suppressed. In accordance with the efforts to prevent, curb the abuse and illicit trafficking of narcotics that have been proclaimed by the National Narcotics Agency (BNN).

The sanctions provided for in Law No. 35 of 2009 concerning narcotics adopts a "double track system", namely in the form of criminal sanctions and action sanctions, rehabilitation is a form of sanctions. ${ }^{9}$ However, based on empirical facts in the field, it shows that law enforcers often do not give narcotics users the right to carry out rehabilitation, even though

7 Dani Krisnawati, Pelaksanaan Rehabilitasi Bagi Pecandu Narkotika Tahap Penyidikan Pasca Berlakunya Peraturan Bersama 7 (Tujuh) Lembaga Negara Republik Indonesia, Laporan Hasil Penelitian: Universitas Gajah Mada: Yogyakarta, 2014, hlm: 1-3.

8 The thing that must be kept in mind is that a narcotic addict will not heal itself from his dependence, so this will keep the perpetrator committing the act.

9 The nature of the sanctions in Law No. 35 of 2009 double track system, because based on the victimology review that narcotics addicts are self-victimizing victims, namely victims as perpetrators, victimology still determines narcotics abuse as victims, even though victims of criminal acts / crimes they commit themselves. Therefore, narcotics addicts who are also victims deserve protection. However, because narcotics addicts are also perpetrators of a crime, they must also be punished, because of this it is said that the double track system in the formulation of sanctions against criminal acts of narcotics abuse is the most appropriate. The double track system in the formulation of sanctions against narcotics abuse is a criminal law policy in the formulation of provisions governing the sanctions given to narcotics abuse offenders, namely in the form of criminal sanctions and sanctions considering the perpetrators of narcotics abuse have a slightly different position from other criminal offenders. On the one hand, he is a perpetrator of a criminal act who must be punished, but on the other hand he is a victim of the crime he has committed himself, so it is necessary to carry out an action in the form of rehabilitation. Determination of sanctions against narcotics addicts, whether to apply criminal sanctions or action sanctions, the determination rests with the judge. See in: Putri Hikmawati, Analisis Terhadap Sanksi Pidana Bagi Pengguna Narkotika, Dalam: Jurnal Negara Hukum: Vol. 2, No. 2, November 2011, hlm: 335. 
in Law No. 35 of 2009 concerning narcotics, there is guaranteed rehabilitation for narcotics addicts. In addition, due to the limited number of assistants or counsellors, the number of narcotics addicts who are reached by the rehabilitation program is limited. ${ }^{10}$

Rehabilitation is a form of punishment for addicts or drug users, for the norm itself, as stated in Article 103 of Law No. 35 of 2009 concerning Narcotics, has no problem with the interpretation of norms or legal interpretations, because it is clear that in every narcotics case, law enforcers and decision-makers are required to comply with the same rules, namely Law No. 35 of 2009 on narcotics. The law is a "special" regulation that deviates from the criminal system that has been in effect in Indonesia. It is said to be "special" because the Narcotics Law adopts a "double track system" for self-punishment of abusers with an obligation for all courts in Indonesia to punish rehabilitation.

The application of criminal law in the form of imprisonment for victims of narcotics abusers has been proven to have failed because every year the number of victims of abusers who go to prison increases. Through the Supreme Court Circular (SEMA) No. 3 of 2011 concerning the Placement of narcotics abuse victims in Medical Rehabilitation and Social Rehabilitation Institutions. This SEMA strengthens Articles 54-59 of Law No. 35 of 2009 concerning narcotics, Articles 13-14 of Government Regulation no. 25 of 2011, which in essence is that Narcotics abusers who are faced with the law are placed in medical and social rehabilitation places during the judicial process. The Attorney General also responded to a similar prospect by issuing SEJA No. SE002 / A / JA / 02/2013 concerning the Placement of Victims of Narcotics Abuse to the Medical Rehabilitation and Social Rehabilitation Institutions and the technical rules in implementing SEJA are contained in SEJA No. SEOO2 / A / JA / 02/2013 concerning the Placement of Narcotics Abuse Victims to Medical Rehabilitation and Social Rehabilitation Institutions.

Then the Joint Decree of the Chairman of the Supreme Court of the Republic of Indonesia, Minister of Law and Human Rights of the Republic of Indonesia, Minister of Health of the Republic of Indonesia, Minister of Social Affairs of the Republic of Indonesia, Attorney General of the Republic of Indonesia, Chief of the National Police of the Republic of Indonesia, and Head of the National Narcotics Agency of the Republic of Indonesia Number. 01 / PB / MA / III / 2014 - 03 Year 2014 - 11 / Year 2014 - PERoo5 / A / JA / 03/2014 - 1 Year 2014 PERBER / 01 / III / 2014 / BNN (National Narcotics Agency) About the Handling of Narcotics Addicts and Victims of Narcotics Abuse in Rehabilitation Institutions with the aim of realizing optimal coordination and cooperation in solving narcotics problems in order to reduce the number of narcotics addicts and victims of narcotics abuse through treatment, treatment and recovery programs in the handling of narcotics addicts and victims of narcotics abuse as suspects, defendants or prisoners, while still carrying out the eradication of illicit narcotics trafficking. This means that drug addicts no longer end up with imprisonment penalties but end up in rehabilitation, because sanctions for addicts are agreed in the form of rehabilitation. ${ }^{11}$

\footnotetext{
${ }^{10}$ Chairman of the Indonesian Addiction Counselor Certification Board, Benny Ardjil, said that out of a total of around 3.6 million drug addicts, only $10 \%$ are covered by the therapy and rehabilitation program. See: Benny Ardjil, Improvement of Rehabilitation Facilities, SINAR BNN Magazine, Edition 3, 2010, pages: 2425, then stated that: Whenever police officers find someone or a group of people using drugs, the mind quickly concludes that the person is a drug addict. Even though this is not always the case, addicts do use drugs. Meanwhile, those who use drugs are not always addicts. Because if he uses it for the first time, has just tried, he is called a trial drug user or experimental user.

${ }^{11}$ The establishment of this Joint Regulation is aimed at providing technical guidelines in the handling of narcotics addicts as suspects, defendants or prisoners in undergoing medical rehabilitation and/or social rehabilitation. Apart from that, it also aims to ensure that the medical rehabilitation and social rehabilitation processes at the investigation, prosecution and trial levels can be carried out in a synergistic and integrated manner. After the enactment of this Joint Regulation, the implementation of this Joint Regulation itself will
} 
On the basis of the formation of the Joint Regulation, an Integrated Assessment Team (TAT) was established at the central, provincial, district / city levels consisting of a team of doctors and a legal team tasked with carrying out an analysis of the role of suspects arrested at the request of investigators related to illicit trafficking. Drugs especially for addicts. The team then carries out legal analysis, medical analysis and psychosocial analysis and develops a rehabilitation plan that outlines how long the rehabilitation will take. The results of the assessment are used as a complete case file, which functions as information such as visum et repertum. The results of the analysis will sort out the role of the suspect as an abuser, an abuser as well as a dealer. The assessment team's analysis of abusers will produce levels of addicts ranging from heavy, medium and light addicts where each level of addicts requires different rehabilitation.

An addict and a victim of narcotics abuse is a victim of narcotics so he deserves to be called a sick person. As a result, an addict and a victim of narcotics abuse must undergo treatment by placing him in a medical rehabilitation and/or social rehabilitation institution. The placement of addicts and victims of narcotics abuse into these rehabilitation institutions is in accordance with the objectives of the Law as mandated in Article 4 letter d of Law No. 35 of 2009 concerning Narcotics.

A problem that is quite crucial and has caught the attention of many circles is that the rehabilitation process itself is very convoluted and time-consuming and costs a lot of money, starting from the process of investigation, prosecution, trial to conviction. The problem in question can be illustrated by the demonstration below;

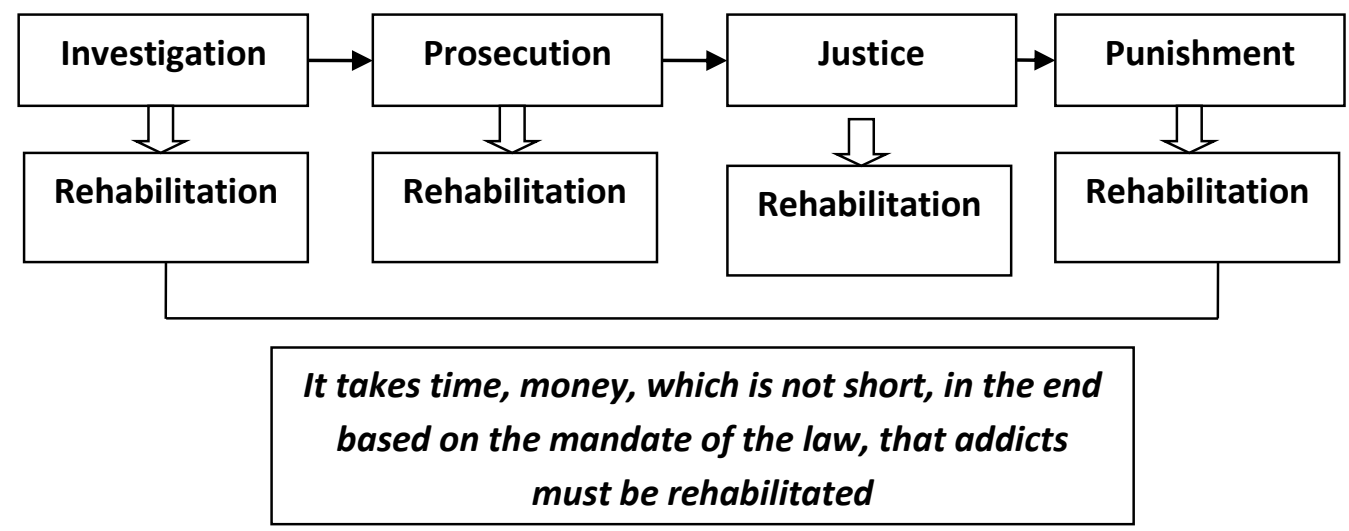

The author as a Police investigator who often handles drug cases is very difficult to carry out the mandate of Article 54 of Law No. 35 of 2009 concerning Narcotics and Regulation of the Head of the National Narcotics Agency No. 11 of 2014 concerning Procedures for Handling Suspects and/or Defendants of Narcotics Addicts and Victims of Narcotics Abuse into Rehabilitation Institutions, namely implementing the Integrated Assessment Team (TAT) mechanism in terms of time, distance and geographic location of our country, costs, and readiness the integrated assessment team officers themselves.

In addition, the existence of the Integrated Assessment team is not evenly distributed throughout the Province or Regency / city, thus it is so difficult just to carry out an assessment of an addict, even though it is not uncommon for investigators to be able to secure large numbers of

be carried out in stages. As an initial stage, the pilot project was carried out in 16 cities and districts namely Batam City, East Jakarta City, South Jakarta City, Bogor Regency, South Tangerang City, Semarang City, Surabaya City, Makassar City, Maros Regency, Samarinda City, Balikpapan City, City Padang, Sleman Regency, Pontianak City, Banjar Baru City, and Mataram City. The selection of cities and regencies is based on the readiness of infrastructure such as rehabilitation centers. It can be opened the website address: http://www.renewalvoice.com/home/. 
drug addicts every day, because of this difficulty investigators can only take two steps, namely carrying out a fingerprint process and detaining suspected drug abusers / addicts, then proceeding to the next process by heeding article 54 of Law 35 of 2009 on Narcotics or the second step of the National Police Investigator with confidence and judgment in the investigation or investigation stage that they believe that a person the suspect is a drug user who needs immediate treatment or rehabilitation to carry out an assessment of the Report Obligatory Recipient Institution (IPWL) or a Rehabilitation institution in the jurisdiction of each investigator working and the results of the medical assessment are immediate $\mathrm{g}$ admitting the suspect to a government or non-government rehabilitation institution, however, this is done by the investigator not in accordance with existing regulations and the investigator realizes that there is no protection and legal certainty for the investigator, but on the other hand the investigator provides direct legal protection for drug users and the actions taken by the Police investigators in this second step were very effective and efficient.

Why put more emphasis on the rehabilitation process? This is necessary in order to operationalize Article 54 of Law no. 35 of 2009 concerning Narcotics in which narcotics addicts are required to undergo medical rehabilitation and social rehabilitation. Then when this legal process is running, the verdict that will apply in accordance with the mandate of the law is the rehabilitation verdict. The problem is, why do you have to go through a legal process if in the end it is rehabilitation, how much is the cost for something like this? The costs incurred to carry out rehabilitation are money from the State, if at every stage in the legal process to take a rehabilitation sentence, you can imagine how much it costs for one addict if the process of investigation, prosecution, trial and punishment is carried out and ultimately rehabilitation too, this is very unlikely. very effective so that the value of legal efficiency is lost, even though on the other hand this process is to avoid the value of legal uncertainty, however this should be resolved with a future criminal law perspective as contained in the Draft Criminal Procedure Code, namely the role of preliminary examining judges at the investigation stage and/or prosecution of a criminal act.

Rehabilitation of addicts is also a form of reducing the over capacity of prisons or detention centers which tends to trigger new problems that are no less significant. Many cases have occurred in prisons, including riots, crimes in prisons, and other serious problems. So far, drug cases are the biggest contributor to prisons or remand centers in Indonesia. Seeing this situation, it takes extra hard work from various parties so that this problem of overcapacity can be overcome or at least overcome.

\section{Literature review}

The paradigm that the writer adapts from Sellin and Wolfgang, the victim of narcotics abuse is "mutual victimization", where the perpetrator who becomes the victim is the perpetrator himself, as well as prostitution and adultery. Based on the opinions of legal experts regarding the typology of victims from a victimological perspective, it can be stated that a drug addict is a "selfvictimizing victim", that is, someone who becomes a victim because of his own actions. However, there are also those who classify it as "victimless crime" because these crimes usually do not target victims, all parties are involved.

In addition, it can also be categorized as "crime without victim". The definition of a victimless crime means that this crime does not cause victims at all but the perpetrator as the victim. Meanwhile, in the category of crime, an evil act must cause a victim and the victim is someone else. This means that if you are the only victim yourself, it cannot be said to be a crime. In terms of the position of victims of Narcotics abuse in the judicial system, their position is still underestimated, even though they can be categorized as "sick people" who are the joint responsibility of the government, the community component with the rehabilitation program. 
Legal Protection for Drug Abuse Victims is based on Law No. 35 of 2009 concerning Narcotics, when viewed from "straafsoot" (type of sanction) is included in the "double track system", which provides criminal sanctions and sanctions for action. Criminal sanctions are in the form of death penalty, imprisonment, imprisonment, fines and sanctions for action, in the form of rehabilitation. In Law Number 35 of 2009 concerning Narcotics, it is stated in Article 54, that; Narcotics addicts and victims of Narcotics abuse are required to undergo medical rehabilitation and social rehabilitation. Addicts and victims of Narcotics abusers must be rehabilitated, Judges can decide and assign a Narcotics addict to undergo treatment and/or treatment, the period of undergoing treatment and/or treatment for Narcotics addicts, is counted as a period of serving a sentence.

Regulations regarding Rehabilitation are regulated in Law No. 35 of 2009 Article 54 Article 59. With the regulation regarding Rehabilitation in the Narcotics Law, the victims of narcotics abuse are categorized as "sick people" who are entitled to receive treatment (in this case through Rehabilitation). In Article 127 paragraph 3 concerning penalties for Narcotics Abusers, the regulations stipulate that:

In the case of an abuser as referred to in paragraph 1, who can be proven or proven to be a Victim of Narcotics abuse, then the abuser is obliged to undergo medical rehabilitation and social rehabilitation.

Article 127 in Law No. 35 of 2009 applies 2 (two) sanctions, namely imprisonment and action sanctions. On the one hand, Narcotics abusers are subject to criminal sanctions, but if proven to be a Victim of Narcotics abuse, they are entitled to receive treatment in the form of medical rehabilitation and social rehabilitation. The purpose of law itself is in conventional view ${ }^{12}$ is in order to realize justice ("rechtsgerechtigheid"), benefit ("rechtsutiliteit") and legal certainty ("rechtszekerheid"). Thus, the arguments against the purpose of this law are as follows:

The law protects a person's interests by allocating a power to him to act in his interests. This allocation of power is carried out in a measured manner, in a sense, its breadth and depth are determined. Such power is called right. But not every power in society can be called a right, but only certain powers which become the reason for the attachment of that right to someone. ${ }^{13}$

Legal protection is an act or an effort to protect people from arbitrary actions by a ruler who is not in accordance with the rule of law, to create order and tranquility so as to enable humans to enjoy their dignity as humans. ${ }^{14}$ So it can be said that what is called legal protection is: ${ }^{15}$

Activities to protect individuals by harmonizing the relationship of values or rules

that are incarnated in attitudes and actions in creating order in the interaction of

life among humans.

The character of "preventive" legal protection as stipulated in Law No. 35 of 2009 concerning Narcotics, has the same meaning as criminal law which is "ultimum remedium". ${ }^{16}$

${ }_{12}$ Achmad Ali, Menguak Tabir Hukum (Suatu Kajian Filosofis dan Sosiologis), PT. Gunung Agung Tbk: Jakarta, 2002, hlm: 85 .

${ }_{13}$ Satjipto Rahardjo, Ilmu hukum, Citra Aditya Bakti : Bandung, Cetakan ke - V 20oo, hlm: 53.

${ }^{14}$ Setiono, Rule of Law (Supremasi Hukum), Magister Ilmu Hukum Program Pascasarjana Universitas Sebelas Maret : Surakarta, 2004, hlm: 3.

15 Muchsin, Perlindungan dan Kepastian Hukum bagi Investor di Indonesia, Magister Ilmu Hukum Program Pascasarjana Universitas Sebelas Maret : Surakarta, 2003, hlm: 14-15.

${ }^{16}$ In Jeremy Bentham's view, Criminal Law should not be imposed / used if it is groundless, needless, unprofitable or inefficacious. Likewise, Packer once reminded that the use of criminal sanctions indiscriminately and coercively will cause said criminal means to become a "prime threatener". Due to the limitations of penalties, two policies should be used in the prevention of crime (criminal politics), namely 
Suffering of a special nature in criminal law is very different from suffering in civil law, because in criminal law there is an institution of deprivation of liberty or an institution for limiting freedom that can be imposed by judges against people who have violated the norms regulated in the law. In criminal law, even in it, people also recognize the institution of deprivation of life in the form of the death penalty, which in fact is not known to people in other laws generally.

With regard to special sufferings in the form of (criminal) penalties, criminal law has a separate place among other laws, which according to criminal law scholars should be seen as an "ultimum remedium" or as a last resort to improve human behavior. Then, in its application, criminal law must be accompanied by the strictest possible restrictions. The term "ultimum remedium" is used by the Dutch minister of justice to answer a question by a member of parliament named Mckay in the context of the discussion of the Criminal Code, which said that he had failed to find a legal basis regarding the need for a sentence for someone who had committed an offense.

Regarding the statement from McKay, the Dutch Minister of Justice Modderman said, among others, the following: ${ }^{17}$

"I believe that this principle is not only perpetuated between the lines, but is expressed repeatedly, perhaps in a different form. The principle is this: that all may be punished that which is in the first place unjust. This is a conditio sine qua non. In the second place, there is an additional demand that it be an unjust one, which experience has taught that it cannot be properly controlled by any other means. The punishment remains an ultimate remedy. Of course, there are objections to any criminal threat. Any sensible person can understand this without explanation. That does not mean that one should omit punishment, but that one must always weigh against each other the advantages and disadvantages of the punishment, and agree that the rigid does not become a cure worse than the disease ..."

Related to rehabilitation in the provisions of Law no. 35 of 2009 concerning narcotics, in terms of the Pancasila philosophy, the principle of "ultimum remedium" contains moral messages and humanity is not merely law as a means or tool but law as a value. In addition to this, the legal function of "ultimum remedium" also contains benefits, not necessarily being interpreted as repressive ("corrective justice") / "deterren", but also "rehabilitative" and "responsive". ${ }^{18}$ The implied meaning in rehabilitation based on Pancasila and the Preamble to the 1945 Constitution is that if a case can be resolved through other channels (kinship, negotiation, mediation, civil or administrative law), that route should be followed first. In this case, the nature of criminal sanctions as the ultimate weapon or "ultimum remedium" when compared to civil or administrative sanctions has harsh sanctions. One thing that distinguishes criminal law from other laws, both public law and private law, is the matter of sanctions. Criminal sanctions can be in the form of imprisonment and imprisonment which makes the convict must be isolated and separated from his family and society. The cruelest penalty is the death penalty to separate the convict from his life.

When talking about the value of "efficiency" and "rationality" in law, it cannot be separated from the thought of law as a value. In the development of scientific thought and legal theory, a framework of thought called Integrative Legal Theory, was developed, which was put

penalties using criminal sanctions (including criminal law politics) and non-penal policies (including using administrative sanctions, civil sanctions and others).

${ }_{17}^{17}$ PAF Lamintang, Dasar - Dasar Hukum Pidana Indonesia, PT. Citra Aditya Bakti: Bandung, 2011, hlm: 17.

${ }^{18}$ Romli Atmasasmita, Moral Pancasila, Hukum \& Kekuasaan, PT. Refika Aditama: Bandung, 2020, hlm: 21. 
forward by Romli Atmasasmita ${ }^{19}$ that law can be interpreted as a system of norms and law as " $a$ system of behavior", and law as "a value system".

The following is a chart of the integrative law theory proposed by Romli Atmasasmita;

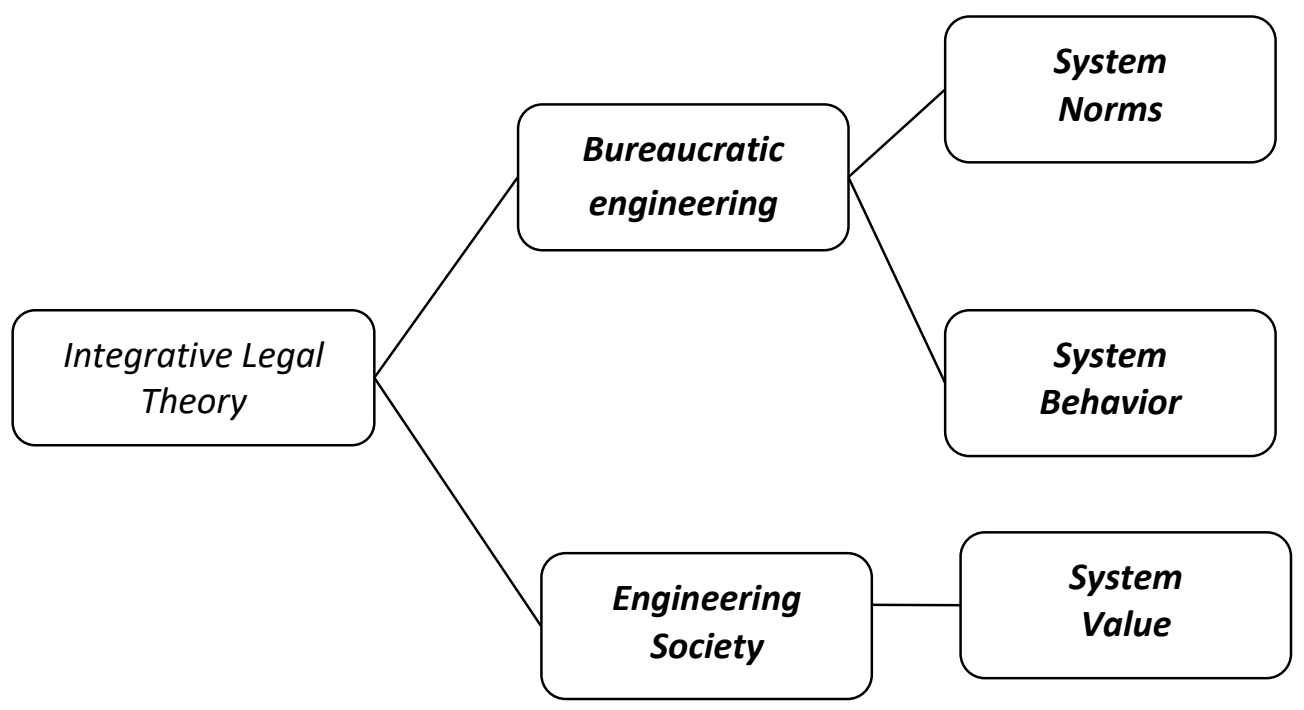

What was stated by Romli Atmasasmita in the context of the life of the Indonesian people must be seen as a unit of thought that is suitable in facing and anticipating the worst possibility of the current century of globalization by not breaking away from the traditional nature of Indonesian society which still prioritizes moral values and social values. The three legal natures are outlined in one container called tripartite character of the Indonesian legal theory of Social and Bureaucratic Engineering (BSE). ${ }^{20}$

Romli Atmasasmita's way of thinking, which adds a value system to a rule of law and the formation of laws that are made must be adapted to the development of the dynamics of society and pay attention to aspects of justice ${ }^{21}$ and can provide protection to create legal order, this is where law functions as a rule. This is in accordance with the foundation of Roscoe Pound's ${ }^{22}$ sociological journalism theory which emphasizes that law is a tool for building society. "Law as a tool of social engineering", in line with Roscoe Pound's thinking, Eugen Erlich proposes a conception of a living law with a legal meaning that is not found in formal legal materials but in society. ${ }^{23}$

Mochtar Kusumaatmadja proposed a conception of law as a means of reforming society in development based on his following thoughts: ${ }^{24}$

19 Romli Atmasasmita, Teori Hukum Integratif: Rekonstruksi Terhadap Teori Hukum Pembangunan dan Teori Hukum Progresif, Genta Publishing : Yogyakarta, 2012, hlm. 96.

${ }^{20}$ Romli Atmasasmita, Teori Hukum Integratif: Rekonstruksi Terhadap Teori Hukum Pembangunan dan Teori Hukum Progresif. Ibid, hlm: 96.

${ }^{21}$ John Rawls, Teori Keadilan: Dasar-Dasar Filsafat Politik Hukum Mewujudkan Kesejahteraan Sosial Dalam Negara. Terjemahan: Uzair Fauzan dan Heru Prasetyo. Yogyakarta: Pustaka Pelajar, 2001, hlm. 3.

22 Yesmil Anwar \& Adang, Pengantar Sosiologi Hukum, PT. Gramedia Widiasarana.

${ }^{23}$ Lili Rasjidi dan I. B. Wyasa Putra, Hukum Sebagai Suatu Sistem, Mandar Maju: Bandung, 2003, hlm. 79.

24 Mochtar Kusumaatmadja, Fungsi Hukum dan Perkembangan Hukum Dalam Pembangunan Nasional. Bandung: Bina Cipta, 1976, hlm. 9. 
(1) That there is regularity or order in the development or renewal effort which is something that is wanted or even deemed (absolutely) necessary;

(2) Whereas law in the sense of a rule or legal regulation can indeed function as a tool (regulator) or a means of development in the sense of channeling human activities in the direction desired by development or renewal.

The meaning of law as a manifestation of political policy is regulation, or what is often referred to as positive law (currently applicable law). Therefore, the regulation is strongly influenced by the ruler's view of the law. According to Mochtar Kusumaatmadja, legal reforms are:

Legal reform efforts should begin with the conception that law is a means of reforming society. Law must be a tool for reform in society (social engineering), which means that the law can create conditions that lead people to a harmonious state in improving their lives. ${ }^{25}$

In line with Mochtar Kusumaatmadja's opinion above, Sunaryati Hartono ${ }^{26}$ argues that the meaning of legal development will include the following: Making things better (making things better); change for the better; doing something that didn't exist before; or negating something that was in the old system, because it is not needed and is not compatible with the new system.

As the mandate of the 1945 Constitution that the administration of public welfare, the formation of various laws and regulations is very important. To reform Indonesian criminal law in order to achieve the goal of a country, namely a country that is prosperous as well as just and prosperous, it is necessary to have a conducive atmosphere in all aspects including legal aspects. One of the policies to provide social protection ("social defense policy") is the prevention and control of actual or potential crimes or crimes. All efforts to prevent and overcome this crime / crime are included in the area of criminal policy ("criminal policy"). ${ }^{27}$

\section{Findings and discussion}

Rehabilitation is a form of punishment for addicts or drug users, for the norm itself, as stated in Article 103 of Law No. 35 of 2009 concerning Narcotics, has no problem with the interpretation of norms or legal interpretations, because it is clear that in every narcotics case, law enforcers and decision-makers are required to comply with the same rules, namely Law No. 35 of 2009 on Narcotics. This law is a "special" regulation that deviates from the criminal system that has been in effect in Indonesia so far. It is said to be "special" because this law adheres to a "double track system", ${ }^{28}$ the punishment of self-abuse for abusers with an obligation for all judicial institutions in Indonesia to punish rehabilitation.

25 Mochtar Kusumaatmadja, Hukum, Masyarakat dan Pembinaan Hukum Nasional, Bina Cipta: Bandung, 2006, hlm. 8-9.

${ }_{26}$ Sunaryati Hartono, Hukum Ekonomi Pembagunan Indonesia, BPHN: Jakarta, 1999.

27 To accommodate the needs and aspirations of its people, the Indonesian state has determined a social policy in the form of a policy to realize social welfare (social welfare policy) and a policy to provide social protection (social defense policy). See, Barda Nawawi Arief. Masalah Penegakan... Op. cit., hlm. 73.

${ }^{28}$ In this case, there is a two-track system regarding sanctions in criminal law. Although the existing literature has never found an explicit affirmation of the basic idea of a double track system, from the background of its emergence, it can be concluded that the basic idea of the system is the equality of criminal sanctions and sanctions for action. This idea of equality can be traced through developments in the criminal law sanction system from the classical to the modern and the neo-classical. Likewise with rehabilitation and prevention (as the goal of the mother from the type of action sanction / treatment). Although this method has special features in terms of the perpetrator's resocialization process so that it is expected to be able to 
The legality of the arrangement for the rehabilitation of victims of drug abuse must first be referred to the rules of a general nature ("lex specialis"). This means that drug abuse is a criminal act, thus it must be seen in general regulations, namely the Criminal Code (KUHP) and the Criminal Procedure Code (KUHAP). In these two regulations the rehabilitation arrangement is contained in Article 1 number 23 KUHAP and Article 97 KUHAP.

KUHAP and Law No. 35 of 2009 on Narcotics both require drug addicts to be rehabilitated rather than imprisoned and treated as criminals. It is clear and normal that the implementation of rehabilitation according to the Criminal Procedure Code does not at all pertain to the results of the actions of a criminal offender, but rehabilitation is nothing but a means (media) and an effort to restore the good name, position and dignity of a person who has undergone enforcement action law in the form of arrest, detention, prosecution or examination in court proceedings. ${ }^{29}$

As a way out in terms of rehabilitation of victims of drug abuse is to make a special regulation without a legal process, so when the integrated legal and medical assessment team (TAT) states that the person concerned is a drug addict, the rehabilitation process can be carried out without a continuous legal process, in order to cure the health condition of addicts, this is an effective and efficient step to reduce the imposition of state costs to overcome addicts. Efforts to enact laws that live in society (the living law) are indeed a development of the principle that the current criminal law wants to shift from "retributive justice" to "ultimum remedium" and "restorative" justice. The shift from "retributive justice" to "ultimum remedium" and "restorative" justice, so that the principle of justice and expediency becomes one of the main objectives other than creating a humanist criminal law and recognizing human rights. This is also a development of criminal law theory and criminology in the world which aims to provide nuances of "peace keeping" or the creation of a sense of peace in society by reducing things that are inappropriate or degrading human dignity.

So with the application of the principle of "ultimum remedium", in practice it is hoped that no one will be punished twice for his actions as has been the case, namely criminal punishment and rehabilitation, especially for minor offenses or mistakes, namely as a drug abuser. This effort aims to create a balance in the life of Indonesian society which is still thick based on the principles of deliberation and Pancasila.

The ideas and ideas above to be able to realize special rules regarding drug rehabilitation are the implementation of a criminal law policy in essence an attempt to realize criminal legislation to suit the circumstances at a certain time ("ius constitutum") and the future ("ius constituendum"). The logical consequence is that criminal law policy is identical to "penal reform" in a narrow sense. Because, as a system, criminal law consists of culture ("cultural"), structure ("structural"), and substance ("substantive").

Assessed from the perspective of legal politics, criminal law politics seeks to make and formulate good criminal legislation. According to Marc Ancel, a "penal policy" is both a science

restore a person's social and moral quality so that he can reintegrate into society, it is proven to be less effective in repairing a criminal because it is considered too spoiling him. Precisely as said by C.S. Lewis, that the rehabilitation approach through treatment has invited individual tyranny and denial of human rights. Look inside: Sholehuddin, Sistem Sanksi Dalam Hukum Pidana Ide Dasar Double Track System dan Implementasinya, Raja Grafindo Persada: Jakarta, 2003, hlm: 50.

29 J. C. T. Simorangkir (et al.), Kamus Hukum, Aksara Baru: Jakarta, 1980, hlm: 147, bahwa "rehabilitasi adalah pemulihan, pengembalian kepada keadaan semula”.

$3^{\circ}$ Regarding the notion of a legal system consisting of cultural, structural and substantive, it can be seen in the writings of Lawrence M. Friedman in Legal culture and social development, p. 1002-1010 and Law and society: An introduction, New Jersey: Prentice Hall Inc, 1977, p. 6-7. 
and an art that aims to enable better formulated positive legal rules. Positive legal regulations are here defined as laws and regulations on criminal law. Therefore, the term "penal policy" according to March Ancel is the same as the term "policy or criminal law politics". The implementation in terms of rehabilitation for drug addicts / abusers, that the criminal law should not be imposed / used if it is "groundless", "needless", "unprofitable or inefficacious" ${ }^{31}$ Likewise Herbert L. Packer once reminded that the use of criminal sanctions indiscriminately / generalizing and being used coercively ("coercively") will cause the criminal means to become a "prime threatener".

Due to the limitations of "penal", two policies should be used in overcoming crime (criminal politics), namely the "penal" policy using criminal sanctions (including the field of criminal law politics) and "non-penal" policies (including using administrative sanctions, civil sanctions and others). The two policies are carried out through an integrated approach ("integrated approach") between politics, crime and society and integration ("integrity") between efforts to combat crime with penal and "non-penal" means.

\section{Conclusion}

One part of this social policy is the law enforcement policy, including the legislative policy. Meanwhile, the "criminal policy" itself is part of the law enforcement policy. So, in essence, the policy used to tackle drug crimes is a policy of using criminal law (a "penal policy"). This rehabilitation policy is very thick with the nuances of "decriminalizing" drug abusers. The form of legal protection for drug abusers or addicts is very clear, namely following the legal rules in Law No. 35 of 2009 concerning Narcotics, namely with rehabilitation and then reinforced back through the Supreme Court Circular (SEMA) No. 4 of 2010 and renewed by the Supreme Court Circular (SEMA) No. 03 of 2011, that drug addicts must be placed in a rehabilitation institution while waiting for the trial process and when the judge ruled that these addicts also receive protection by being rehabilitated without imprisonment or criminal punishment.

The criminal law must be placed in the position of "ultimum remedium", that the use of punishment and imprisonment must be ruled out or as a last resort. The future rehabilitation institute is at least equivalent to Singapore, namely providing rehabilitation without imprisonment. That is, the addict is completely recovered, both mentally and physically, from drug addiction. Rehabilitation institutions must be able to provide justice both legally and socially. The concept of "ultimum remedium" is equivalent to the concept of "Restorative Justice", in both psychological and physical recovery from victims of drug abuse.

\section{Acknowledgements}

This research did not receive any specific grant from funding agencies in the public commercial, or not-for-profit sectors.

The author declares no competing interests.

${ }^{31}$ Barda Nawawi Arief, Bunga Rampai Kebijakan Pidana, PT. Citra Aditya Bakti, Bandung, 1996, hlm. 2. 


\section{References}

Alam, A. S. (2010). Pengantar Kriminologi [Introduction to criminology]. Makassar: Refleksi Books.

Ali, A. (2005) Keterpurukan Hukum di Indonesia: Penyebab dan Solusinya [Downsides of law in Indonesia: Causes and solutions]. Cetakan Kedua, Bogor: Ghalia Indonesia.

Ancel, M. (1965). Social defense: A modern approach to criminal problems. London: Rotledge \& Kegal Paul.

Andersson, et al. (2014). Alcohol and drug use among European 17-18 year old students. Data from the ESPAD Project.

Anwar, Y., \& Adang (2008). Pengantar Sosiologi Hukum [Introduction to sociology of law]. Jakarta: PT. Gramedia Widiasarana Indonesia.

Arief Mansur, D. M., \& Gultom, E. (2007). Urgensi Perlindungan Korban Kejahatan [The urgency for the protection of victims of crime]. Jakarta: PT. Raja Grafindo Persada.

Ata Ujan, A. (2009). Filsafat Hukum, Membangun Hukum Membela Hukum [Philosophy of law, Building the law defending the law]. Yogyakarta: Kanisius.

Atmasasmita, R. (2012). Teori Hukum Integratif: Rekonstruksi Terhadap Hukum Pembangunan dan Teori Hukum Progresif [Integrative legal theory: Reconstruction of development law and progressive legal theory]. Yogyakarta: Genta Publishing.

BNN (2014). Laporan Akhir Survei Nasional Perkembangan Penyalahguna Narkoba Tahun Anggaran 2014 [Final Report of the 2014 National Survey on the Development of Drug Abusers].

Chazawi, A. (2002). Pelajaran Hukum Pidana Bagian I (Stelsel Tindak Pidana, Teori-Teori Pemidanaan, dan Batas Berlakunya Hukum Pidana) [Criminal law lessons Part I (Criminal action system, criminal theory, and the limits of applicability of criminal law)]. Jakarta: RajaGrafindo Persada.

Cooter, R., \& Ullen, Th. (2008). Law and economic. $5^{\text {th }}$ edition. London: Pearson Addison Wesley.

Fuller et al. (2007). National report 2007. UK.

Hamzah, A. (1991). Politik Hukum Pidana [Criminal law politics]. Jakarta: RajaGrafindo Persada.

Kaplow, L., \& Shavell, S. (1999). Economic analysis of law. Cambridge: National Bureau of Economic Research.

Kirchheimer, O. (1961). Political justice: The use of legal procedure for political ends. Princeton University Press.

Kusumaatmadja, M. (1976). Fungsi Hukum dan Perkembangan Hukum Dalam Pembangunan Nasional [Legal functions and legal development in national development]. Bandung: Bina Cipta.

Mardani (2008). Penyalahgunaan Narkoba (dalam Perspektif Hukum Islam dan Hukum Pidana Nasional) [Drug abuse (in the perspective of islamic law and national criminal law)]. Jakarta: PT. Raja Grafindo Persada.

Martono, L. H., \& Joewana, S. (2005). Modul Latihan Pemulihaan Pecandu Narkoba Berbasis Masyarakat Untuk Pembimbing Dan Pecandu Narkoba [Community-based drug addict restoration exercise module for advisors and drug addicts]. Jakarta: Balai Pustaka.

Nawawi Arief, B. (2010). Bunga Rampai Kebijakan Hukum Pidana [Interest of criminal law policies]. PT. Citra Aditya Bakti: Bandung.

(2007). Pedoman Pencegahan Penyalahgunaan Narkoba Bagi Pemuda (Stop Narkoba Atau Mati $\mathrm{Sia}-\mathrm{Si}$ ) [Guidelines for the prevention of drug abuse for youth (Stop Drugs or Die - Si)]. Jakarta: Badan Narkotika Nasional Republik Indonesia. 
A. Sonjaya - Construction of the Rehabilitation Model for Drug Abuse in Non-Penal...

Poernomo, B. (1982). Hukum Pidana Kumpulan karangan Ilmiah [Criminal law collection of scientific essays]. Bina Aksara: Jakarta.

Rawls, J. (2001). Teori Keadilan: Dasar - Dasar Filsafat Politik Hukum Mewujudkan Kesejahteraan Sosial Dalam Negara [Theory of Justice: Basis of legal political philosophy of creating social welfare in the State]. Terjemahan: Uzair Fauzan dan Heru Prasetyo. Yogyakarta: Pustaka Pelajar.

Samekto, A. (2005). Studi Hukum Kritis - Kritis Terhadap Hukum Modern [Critical legal studies - Critics to modern law]. Bandung: Citra Aditya Bakti.

Susanto, A. F. (2011). Penelitian Hukum Transformatif-Partisipatoris, Fondasi Penelitian Kolaboratif dan Aplikasi Mix Method Dalam Penelitian Hukum [Transformative-participatory legal research, collaborative research foundations and mix method applications in legal research]. Bandung: LoGoz Publishing. 